\title{
KOMPETISI POLITIK, PENDAPATAN ASLI DAERAH DAN OPINI AUDIT TERHADAP IMPLEMENTASI E-GOVERNMENT
}

\author{
Rinda Dwi Utami \\ rindadu@gmail.com \\ Dini Wahjoe Hapsari \\ Dewa Putra Krishna Mahardika \\ Fakultas Ekonomi dan Bisnis, Universitas Telkom
}

diterima: 9/4/2018; direvisi: 12/11/2018; diterbitkan: 30/4/2019

\begin{abstract}
This study analyzes the influence of political competition, regional original income (PAD) and audit opinion on the implementation of e-government. Political competition is measured by the number of elected provincial DPRD members per period. Regional original income is measured by the acquisition of annual regional original revenues and audit opinion is measured by the results of the BPK's examination of the annual regional financial statements. This research uses quantitative methods and includes descriptive verification categories. The sample was selected using the purposive sampling method, namely the province in Indonesia and contained in the Indonesian e-government Rating (PeGI) in 2012-2015. Hypothesis testing uses panel data statistical methods. The results of the study showed that local original income partially has significant effect on the implementation of e-government. Meanwhile, political competition and audit opinion do not indicate a significant influence on the implementation of e-government.
\end{abstract}

Keywords: e-government; political competition; PAD; audit opinion

\begin{abstract}
Abstrak
Penelitian ini menganalisis pengaruh kompetisi politik, pendapatan asli daerah (PAD) dan opini audit terhadap implementasi e-government. Kompetisi politik diukur dengan jumlah anggota DPRD tingkat provinsi terpilih per periode. Pendapatan asli daerah diukur dari perolehan realisasi pendapatan asli daerah tahunan dan opini audit diukur dari hasil pemeriksaan BPK terhadap laporan keuangan daerah tahunan. Penelitian ini menggunakan metode kuantitatif dan termasuk kategori deskriptif verifikatif. Sampel dipilih menggunakan metode purposive sampling, yaitu provinsi yang ada di Indonesia dan terdapat pada Pemeringkatan e-government Indonesia (PeGI) tahun 2012-2015. Pengujian hipotesis menggunakan metode statistik data panel. Hasil penelitian menunjukkan bahwa secara parsial pendapatan asli daerah berpengaruh signifikan terhadap implementasi e-government. Sedangkan kompetisi politik dan opini audit tidak menunjukkan adanya pengaruh yang signifikan terhadap implementasi e-government.
\end{abstract}

Kata Kunci: e-government; kompetisi politik; PAD; opini audit 


\section{PENDAHULUAN}

E-government merupakan suatu upaya untuk memanfaatkan teknologi informasi dan komunikasi yang dimaksudkan untuk meningkatkan efisiensi, efektivitas, transparansi, akuntabilitas penyelenggaraan pemerintahan dan pelayanan publik. Dalam pelaksanaannya, e-government di Indonesia masih mengalami perkembangan. Pemerintah sendiri masih merancang pedoman yang baku untuk penerapan yang merata di seluruh pemerintahan Indonesia. Implementasi yang belum merata dapat disebabkan oleh adanya hambatan yang berbeda di setiap daerah. Ada banyak hambatan dan tantangan dalam pelaksanaan e-government di negara berkembang. Persoalan mendasar di dalam penyelenggaran e-government tersebut yaitu pertama, inisiatif dan pemaknaan implementasi e-government oleh pemerintah daerah otonom masih bersifat sendirisendiri. Kedua, implementasi melalui situs web daerah tersebut belum didukung oleh sistem manajemen dan proses kerja yang efektif karena kesiapan peraturan, prosedur dan keterbatasan sumber daya manusia. Ketiga, banyak pemerintah daerah mengidentikkan implementasi e-government hanya sekadar membuat situs web pemerintahan daerah saja (web presence) (Sipatuhar dan Sutaryo, 2016).

Dalam menjalankan pemerintahan, pemerintah pusat maupun pemerintah daerah sudah mulai melaksanakan e-government. E-government diterapkan pemerintah mulai dari tingkat kementerian, tingkat provinsi, tingkat kabupaten/kota hingga kecamatan dan kelurahan. Untuk mengukur implementasi e-government, Kementerian Komunikasi dan Informatika (MENKOMINFO) mengadakan pemeringkatan e-government berdasarkan 5 kriteria. Lima kriteria tersebut yakni kebijakan, kelembagaan, infrastruktur, aplikasi dan perencanaan. Adanya indeks pemeringkatan ini diharapkan dapat dijadikan acuan bagi pengembangan dan pemanfaatan Teknologi Informasi dan Komunikasi (TIK) di lingkungan pemerintah, sebagai dorongan peningkatan TIK dilingkungan pemerintah dan melihat peta kondisi pemanfaatan TIK di lingkungan pemerintah secara nasional.

Implementasi e-government jika dilihat dari Pemeringkatan e-Government Indonesia (PeGI) tingkat provinsi tahun 2012 hingga tahun 2015, masih banyak provinsi yang memperoleh kriteria kurang. Grafik pemeringkatan e-government tingkat provinsi tahun 2012-2015 ditunjukkan pada Gambar 1.

Dari Gambar 1 terlihat bahwa masih banyak provinsi yang memperoleh kriteria kurang bahkan sangat kurang. Pada tahun 2012, terdapat 13 provinsi dengan kriteria kurang dan 3 provinsi pada kriteria sangat kurang. Di tahun 2013 nilai PeGI mulai meningkat dilihat dari jumlah provinsi dengan kriteria kurang menjadi 10 provinsi. Secara umum PeGI mengalami penurunan nilai rata-rata pada tahun 2014, namun kembali meningkat pada tahun 2015. Hal ini dapat dikaitkan dengan diadakannya pemilihan umum pada tahun 2014 yang mempengaruhi berbagai kebijakan yang dibuat setelah pergantian struktur pemerintah daerah. Walaupun nilai rata-rata PeGI kembali meningkat di tahun 2015, masih ada 7 provinsi yang berada pada kriteria kurang. Hal ini menunjukkan perkembangan implementasi e-government belum merata pada tingkat provinsi.

Salah satu bentuk implementasi e-government yaitu pengungkapan melalui website pemerintahan daerah, tidak hanya terbatas pada pengungkapan informasi keuangan saja tetapi termasuk pengungkapan informasi non keuangan. Variabel independen yang digunakan dalam penelitian ini adalah Kompetisi Politik, Pendapatan Asli Daerah dan Opini Audit.

Kompetisi politik secara umum dapat dipahami sebagai tingkat daya saing untuk menduduki suatu jabatan strategis pada pemerintahan. Lembaga legislatif (DPRD) merupakan lembaga yang memiliki posisi dan peran strategis terkait dengan pengawasan keuangan daerah guna mengontrol kebijakan keuangan daerah secara ekonomis, efisien, efektif, transparan dan akuntabel. Pemerintah daerah bersama DPRD mengatur urusan pemerintahan daerah yang menjadi kewenangannya, sehingga banyaknya anggota DPRD terpilih yang bertugas akan mempengaruhi pengawasan terhadap pemerintahan. Pengawasan tersebut meliputi operasional pemerintahan, termasuk pelaksanaan e-government. Sejalan dengan teori agensi dimana masyarakat sebagai prinsipal dan para anggota dewan sebagai agen, para politikus mengharapkan mendapatkan suara pemilih dari masyarakat lebih banyak, sehingga mereka berusaha untuk memenuhi kebutuhan masyarakat pemilih (Al-Naimat, 2013).

Pendapatan asli daerah (PAD) menurut UndangUndang Nomor 33 Tahun 2004 tentang Perimbangan Keuangan antara Pemerintah Pusat dan Daerah adalah pendapatan yang diperoleh daerah yang dipungut berdasarkan peraturan daerah sesuai dengan peraturan perundang-undangan. Pendapatan asli daerah merupakan salah satu sumber pendapatan utama yang digunakan pemerintah daerah untuk menjalankan pemerintahan, sehingga besarnya pendapatan yang diperoleh akan mempengaruhi pemenuhan sarana prasarana dalam rangka pembangunann daerah. E-government dalam penerapannya membutuhkan biaya yang besar. Hal ini memungkinkan jika kesejahteraan ekonomi daerah sudah baik, pemerintah akan mempunyai biaya yang cukup untuk melayani masyarakat melalui implementasi e-government (Sipatuhar dan Sutaryo, 2016).

Opini audit merupakan pernyataan profesional pemeriksa mengenai kewajaran informasi keuangan yang disajikan dalam laporan keuangan yang didasarkan pada kriteria, kesesuaian dengan standar akuntansi pemerintahan, kecukupan pengungkapan (adequate disclosure), kepatuhan terhadap peraturan perundang- 
undangan dan efektifitas sistem pengendalian internal (Faud, 2015). Daerah yang memperoleh opini audit wajar tanpa pengecualian (WTP) berarti telah menjalankan pemerintah dengan baik serta telah menerapkan asas akuntabilitas dan transparansi. Akuntabilitas dan transparansi tersebut dapat dipengaruhi dengan adanya implementasi e-government, salah satunya dengan pegungkapan melalui website daerah. Hal ini dikarenakan informasi yang disajikan oleh pemerintah daerah dapat dinikmati masyarakat secara terbuka.

Kompetisi politik merupakan tingkat daya saing untuk menduduki suatu jabatan strategis pada pemerintahan. Banyaknya perangkat yang berhasil terlibat dalam posisi strategis ini dapat mengindikasikan semangat yang besar dan tingkat pengawasan yang tinggi dalam mengoptimalkan kinerja pemerintahan. Pada penelitian ini, kompetisi politik diproyeksikan dengan anggota Dewan perwakilan Rakyat Daerah. Banyaknya jumlah anggota DPRD terpilih yang bertugas akan mempengaruhi kebijakan yang diambil oleh pemerintah daerah termasuk implementasi e-government. Semakin banyak jumah anggota DPRD, maka semakin tinggi tingkat pengawasan terhadap pemerintah daerah sehingga e-government dapat lebih diimplementasikan demi mencapai pemerintahan yang lebih baik.

Al-Naimat (2013) menemukan pada penelitiannya bahwa dukungan politik merupakan bagian dari sepuluh faktor utama yang mempengaruhi implementasi e-government. Dewi dan Haryanto (2013) juga menemukan bahwa kompetisi politik berpengaruh positif terhadap implementasi e-government.

Pendapatan Asli Daerah adalah pendapatan yang diperoleh daerah yang dipungut berdasarkan peraturan daerah sesuai dengan peraturan perundangundangan Undang-Undang Nomor 32 Tahun 2004 tentang Pemerintahan Daerah. Pendapatan asli daerah merupakan salah satu sumber pendapatan utama yang digunakan pemerintah daerah untuk menjalankan pemerintahan, sehingga semakin besar pendapatan yang diperoleh maka semakin besar pemenuhan sarana prasarana dalam rangka pembangunan daerah. E-government dalam penerapannya membutuhkan biaya yang besar. Hal ini memungkinkan jika kesejahteraan ekonomi daerah (dilihat dari perolehan PAD) sudah baik, pemerintah akan mempunyai biaya yang cukup untuk melayani masyarakat melalui implementasi e-government. Rahim dan Martani (2015), Dewi dan Haryanto (2013), beserta Sipatuhar dan Sutaryo (2016) menemukan bahwa PAD berpengaruh positif terhadap implementasi e-government.

Opini audit menunjukkan akuntabilitas dan transparansi suatu organisasi. Laporan audit yang berisi pendapat wajar tanpa pengecualian adalah laporan yang paling dibutuhkan oleh semua pihak, baik oleh klien, pemakai informasi keuangan, maupun oleh auditor. Pengungkapkan informasi yang telah memperoleh opini audit wajar tanpa pengecualian kepada masyarakat menunjukkan bahwa kinerja pemerintahan suatu daerah tergolong baik, sehingga memungkinkan implementasi e-government yang lebih baik dibandingkan dengan daerah yang memperoleh opini selain wajar tanpa pengecualian. Implementasi e-government yang dimaksud dicontohkan dengan pengungkapan melalui website daerah. Hal ini didukung oleh penelitian Rahim dan Martani (2015) yang menemukan opini audit memiliki hubungan positif terhadap pengungkapan informasi keuangan pada website pemerintah daerah secara signifikan. Berdasarkan teori dan pengembangan hipotesis maka kerangka pemikiran dalam penelitian ini dapat dilihat pada Gambar 2.

\section{METODE}

Operasionalisasi variabel ditunjukkan pada Tabel 1. Populasi yang digunakan adalah pemerintah daerah tingkat provinsi tahun 2012-2015. Teknik sampling yang digunakan adalah purposive sampling dengan kriteria yaitu provinsi yang konsisten terdapat pada Pemeringkatan e-government Indonesia tahun 20122015. Pemilihan sampel dalam penelitian ini didasarkan pada beberapa kriteria berikut ini: (1) Pemerintah daerah tingkat provinsi di Indonesia tahun 2012-2015; (2) Pemerintah daerah tingkat provinsi di Indonesia yang terdapat pada Pemeringkatan e-Government Indonesia (PeGI) tahun 2012-2015.

Data observasi sebanyak 52 yang terdiri dari 13 (Tabel 2) provinsi dengan periode penelitian selama empat tahun. Teknik analisis yang digunakan pada penelitian ini adalah analisis regresi data panel.

Persamaan analisis model data panel yang digunakan dalam penelitian ini adalah:

$$
\mathrm{Y}=\alpha+\beta_{1} \mathrm{X}_{1 \mathrm{it}}+\beta_{2} \mathrm{X}_{2 \mathrm{it}}+\beta_{3} \mathrm{X}_{3 \mathrm{it}}+\mathrm{e}
$$

Keterangan:

$$
\begin{array}{ll}
\mathrm{Y} & =\text { Implementasi e-government } \\
\alpha & =\text { Konstanta } \\
\beta_{1}, \beta_{2}, \beta_{3}= & \text { Koefisien ragresi masing-masing variabel } \\
& \text { independen } \\
\mathrm{X}_{1 \mathrm{it}} \quad=\text { Kompetisi Politik } \\
\mathrm{X}_{2 \mathrm{it}} \quad=\text { Pendapatan Asli Daerah } \\
\mathrm{X}_{3 \mathrm{it}} \quad=\text { Opini Audit } \\
\mathrm{e} \quad=\text { Error term }
\end{array}
$$

Penelitian ini menggunakan Implementasi e-government sebagai variabel dependen, sedangkan variabel independen yang digunakan adalah Kompetisi Politik, Pendapatan Asli Daerah dan Opini Audit. Data yang digunakan adalah data daftar anggota DPRD tingkat provinsi terpilih, laporan realisasi anggaran pemerintahan daerah tingkat provinsi tahunan dan laporan hasil pemeriksaan BPK pemerintahan daerah tingkat provinsi tahun 2012 sampai dengan tahun 2015. 


\section{HASIL}

Hasil pengujian statistik deskriptif pada Tabel 3. Sepanjang tahun 2012 hingga 2015 terjadi dua kali periode pemilu dimana pada periode 2014/2019 jumlah anggota terpilih bertambah dibandingkan periode sebelumnya. Hal ini dapat menunjukkan bahwa kompetisi politik pada pemerintah daerah meningkat. Berdasarkan hasil pengujian statistik deskriptif, jumlah anggota DPRD terpilih yang paling sedikit adalah 45 orang, yaitu Provinsi Bangka Belitung, Gorontalo dan Sulawesi Barat. Jumlah anggota DPRD terpilih terbanyak berada pada Provinsi DKI Jakarta sebanyak 106 di tahun 2014 dan 2015. Rata-rata keseluruhan variabel kompetisi politik adalah 75,384 dan standar deviasi sebesar 22,743. Hal ini menunjukkan bahwa data dari variabel kompetisi politik mengelompok atau tidak bervariasi.

Rata-rata PAD tahun 2012-2015 adalah sebesar Rp 5,936 triliun dan standar deviasi sebesar Rp 8,157 triliun yang menunjukkan data tidak berkelompok atau bervariasi. Dari 52 data, terdapat 36 data yang berada dibawah rata-rata yang menunjukkan PAD masih belum merata pada pemerintah daerah tingkat provinsi.

Rata-rata opini audit adalah 0,634 dan standar deviasi 0,538 menujukkan data berkelompok atau tidak bervariasi. Dari 52 data, terdapat 33 data yang memiliki opini wajar tanpa pengecualian dan sisanya 19 data selain wajar tanpa pengecualian. Hal ini mengggambarkan bahwa secara keseluruhan opini audit pemerintah daerah tingkat provinsi cenderung baik.

Rata-rata implementasi e-government sebesar 2,565 dan standar deviasai sebesar 0,490 menujukkan data mengelompok atau tidak bervariasi. Dari 52 data terdapat 17 data yang memperoleh predikat kurang dengan nilai PeGI yang kurang dari 2,5. Sedangkan sisanya sebanyak 35 data sudah termasuk kategori baik.

Tahap pertama yang dilakukan adalah memilih antara model fixed effect atau common effect menggunakan uji Chow. Berdasarkan hasil uji Chow diperoleh nilai (cross section chi-square) dan (cross section $F$ ) masing-masing 0,0000 dan 0,0000 lebih kecil dari taraf signifikansi yaitu 0,05 . Sehingga model yang dipilih adalah fixed effect. Selanjutnya dilakukan pengujian untuk menentukan model yang paling sesuai antara fixed effect dengan random effect menggunakan uji hausman. Hasil uji Hausman menunjukkan nilai probabilitas cross section random sebesar 0,5530 . Nilai ini lebih besar dari 0,05 sehingga dapat diambil keputusan bahwa penelitian ini menggunakan random effect model.

Dalam mengestimasi model terbaik yang digunakan dalam regresi data panel, terdapat tiga pengujian yaitu uji signifikasi fixed effect (uji chow) yang digunakan untuk memilih antara metode common effect atau fixed effect. Kedua, uji Hausman yang digunakan untuk memilih metode fixed effect atau random effect. Dan yang terakhir, uji Lagrange Multiplier (LM) yang digunakan memilih antara common effect atau random effect.

Uji Signifikasi Fixed Effect (Uji Chow), merupakan uji yang digunakan untuk memilih antara model yang cocok antara common effect atau fixed effect.

Berdasarkan hasil uji chow pada Tabel 4, diperoleh nilai (cross section chi-square) dan (cross section F) masing-masing 0,0000 dan 0,0000 lebih kecil dari taraf signifikansi yaitu 0,05 . Sehingga dapat diputuskan bahwa penelitian ini lebih cocok menggunanakan model fixed effect. Selanjutnya akan dilakukan pemilihan antara metode fixed effect atau random effect menggunakan uji Hausman.

Berdasarkan hasil uji hausman pada Tabel 5, diperoleh nilai cross section random 0,5530 lebih besar dari taraf signifikansi yaitu 0,05 . Sehingga dapat diambil keputusuan bahwa penelitian ini menggunakan random effect model.

Berdasarkan hasil pengujian data panel dengan menggunakan alat uji, dapat disimpulkan bahwa metode regresi dalam penelitian yang digunakan adalah random effect. Berdasarkan data pengujian, dapat diketahui bahwa persamaan regresi data panel sebagai berikut:

\section{$\mathrm{EGOV}=-3,267987-0,009502 \mathrm{KP}+0,308065 \mathrm{PAD}-$ $0,131453 \mathrm{OA}+\mathrm{e}$}

Persamaan regresi data panel dapat diartikan sebagai berikut: (1) Nilai konstanta sebesar $-3,267987$ menunjukkan apabila variabel independen yaitu kompetisi politik tidak ada, pendapatan asli daerah bernilai nol dan opini audit tidak ada, maka implementasi e-government pada pemerintahan daerah tingkat provinsi adalah sebesar $-3,267987$; (2) Koefisien regresi kompetisi politik $\left(\mathrm{X}_{1}\right)$ sebesar 0,009502 bertanda negatif menunjukkan jika terjadi kenaikan kompetisi politik dengan asumsi variabel lain konstan maka implementasi e-government pada pemerintahan daerah tingkat provinsi akan mengalami penurunan nilai rata-rata pada Pemeringkatan e-government Indonesia (PeGI); (3) Koefisien regresi pendapatan asli daerah $\left(\mathrm{X}_{2}\right)$ sebesar 0,308065 bertanda positif menunjukkan jika terjadi kenaikan pendapatan asli daerah dengan asumsi variabel lain konstan maka implementasi e-government pada pemerintahan daerah tingkat provinsi akan mengalami kenaikan nilai rata-rata pada Pemeringkatan e-government Indonesia (PeGI); (4) Koefisien regresi opini audit $\left(\mathrm{X}_{3}\right)$ sebesar 0,131453 bertanda negatif menunjukkan jika terjadi peningkatan opini audit dengan asumsi variabel lain konstan maka implementasi e-government pada pemerintahan daerah tingkat provinsi akan mengalami penurunan nilai ratarata pada Pemeringkatan e-government Indonesia (PeGI).

Berdasarkan hasil uji metode random effect diperoleh bahwa nilai prob (F-statistic) sebesar 0,020373 $<0,05$ maka H0 diterima sehingga kompetisi politik, 
pendapatan asli daerah dan opini audit secara bersamasama memiliki pengaruh yang signifikan terhadap implementasi e-government pada pemerintahan daerah tingkat provinsi secara simultan.

Berdasarkan Tabel 6 diperoleh nilai R-squared sebesar 0,182948 atau 18\%. Hal ini mengindikasikan bahwa variabel independen yang terdiri dari kompetisi politik, pendapatan asli daerah dan opini audit mampu menjelaskan variabel dependen implementasi e-government sebesar $18 \%$ sedangkan sisanya $82 \%$ dijelaskan oleh variabel lain diluar penelitian.

Berdasarkan Tabel 7 dapat disimpulkan bahwa: (1) Variabel kompetisi politik $\left(\mathrm{X}_{1}\right)$ memiliki nilai probabilitas $0,3072>0,05$, sesuai ketentuan pengambilan keputusan maka $\mathrm{H} 0$ ditolak yang berarti kompetisi politik tidak memiliki pengaruh yang signifikan terhadap implementasi e-government; (2) Variabel pendapatan asli daerah $\left(\mathrm{X}_{2}\right)$ memiliki nilai probabilitas $0,0306<$ 0,05 , sesuai ketentuan pengambilan keputusan maka $\mathrm{H} 0$ diterima yang berarti pendapatan asli daerah memiliki pengaruh yang signifikan terhadap implementasi e-government sebab perubahan pendapatan asli daerah mengakibatkan perubahan implementasi e-government; (3) Variabel opini audit $\left(\mathrm{X}_{3}\right)$ memiliki nilai probabilitas $0,2190>0,05$, sesuai ketentuan pengambilan keputusan maka $\mathrm{H} 0$ ditolak yang berarti opini audit tidak memiliki pengaruh yang signifikan terhadap implementasi e-government sebab perubahan opini audit tidak mengakibatkan perubahan implementasi e-government.

\section{PEMBAHASAN}

Hasil analisis statistik deskriptif menunjukkan bahwa kompetisi politik tertinggi yang diukur dengan jumlah anggota DPRD terpilih pada suatu periode dimiliki oleh Provinsi DKI Jakarta pada tahun 2014 dan 2015 yaitu sebanyak 106 anggota. Sedangkan kompetisi politik terendah dimiliki oleh Provinsi Bangka Belitung, Gorontalo dan Sulawesi Barat dengan jumlah anggota DPRD terpilih sebanyak 45 orang pada tahun 20122015. Rata-rata keseluruhan variabel kompetisi politik adalah 75,384 dan standar deviasi sebesar 22,743. Hal ini menunjukkan bahwa data dari variabel kompetisi politik mengelompok atau tidak bervariasi. Dari 52 data, sebanyak 24 data berada di bawah rata-rata yang berarti jumlah anggota DPRD terpilih kurang atau sama dengan 75 orang.

Pendapatan asli daerah tingkat provinsi tertinggi dimiliki oleh provinsi DKI Jakarta pada tahun 2015 yaitu sebesar. Pada tahun 2012, PAD Provinsi Sulawesi Barat tercatat paling rendah, yaitu sebesar Rp 33,686 triliun. Rata-rata PAD tahun 2012-2015 adalah sebesar Rp 5,936 triliun dan standar deviasi sebesar Rp 8,157 triliun yang menunjukkan data tidak berkelompok atau bervariasi. Dari 52 data, terdapat 36 data yang berada di bawah rata-rata yang menunjukkan PAD masih belum merata pada pemerintah daerah tingkat provinsi.
Opini audit pemerintah tingkat provinsi menggunakan varibel dummy dimana nilai tertinggi adalah 1 yang dimiliki oleh provinsi yang memperoleh opini wajar tanpa pengecualian. Nilai terendah 0 dimiliki oleh provinsi yang memperoleh opini selain wajar tanpa pengecualian. Rata-rata opini audit adalah 0,634 dan standar deviasi 0,538 menujukkan data berkelompok atau tidak bervariasi. Dari 52 data, terdapat 33 data yang memiliki opini wajar tanpa pengecualian dan sisanya 19 data selain wajar tanpa pengecualian. Hal ini menggambarkan bahwa secara keseluruhan opini audit pemerintah daerah tingkat provinsi cenderung baik.

Implementasi e-government tingkat provinsi yang diukur dengan Pemeringkatan e-government Indonesia (PeGI). PeGI tertinggi sebesar 3,39 diperoleh Provinsi Jawa Barat pada tahun 2013 dan DKI Jakarta pada tahun 2015. Implementasi e-government terendah sebesar 1,61 oleh Provinsi Lampung pada tahun 2012. Rata-rata implementasi e-government sebesar 2,565 dan standar deviasai sebesar 0,490 menujukkan data mengelompok atau tidak bervariasi. Dari 52 data terdapat 17 data yang memperoleh predikat kurang dengan nilai PeGI yang kurang dari 2,5. Sedangkan sisanya sebanyak 35 data sudah termasuk kategori baik.

Berdasarkan pengujian hipotesis secara parsial yang telah dilakukan, kompetisi politik memiliki nilai probabilitas $0,3072>0,05$, maka sesuai dengan ketentuan H0 diterima. Artinya kompetisi politik tidak memiliki pengaruh signifikan terhadap implementasi e-government.

Tabel 8 menunjukkan dari 52 data terdapat $46 \%$ dengan kompetisi politik diatas rata-rata, dimana sebesar $17 \%$ termasuk ke dalam PeGI dengan kriteria kurang. Sebesar 54\% kompetisi politik dibawah ratarata dengan PeGI kriteria kurang sebesar 46\%. Provinsi yang cenderung memiliki kompetisi politik dan PeGI kriteria kurang adalah Sulawesi Barat, Bangka Belitung dan Nusa Tenggara Barat. Jawa Tengah yang memiliki kompetisi politik diatas rata-rata yaitu sebanyak 100 orang menunjukkan nilai PeGI yang hampir sama dengan Gorontalo yang hanya memiliki kompetisi politik sebanyak 45 orang. Begitu pula dengan Sumatera Utara dengan nilai kompetisi politik sebanyak 100 orang memiliki rata-rata PeGI yang hampir sama dengan Bangka Belitung yang hanya memiliki nilai kompetisi politik sebesar 45 orang. Hal ini menunjukkan baik kompetisi politik diatas rata-rata maupun dibawah rata-rata, secara umum perolehan PeGI sudah pada kriteria baik. Sehingga dapat dilihat bahwa jumlah anggota DPRD tidak mempengaruhi implementasi e-government. Berdasarkan Undang-Undang No. 8 tahun 2012 tentang penentuan jumlah kursi anggota DPRD terpilih (Undang-Undang No. 8 Tahun 2012 tentang Pemilihan Umum Anggota DPR, DPD dan DPRD Provinsi dan Kabupaten/Kota), kriteria perhitungan besarnya jumlah anggota didasarkan pada jumlah penduduk. Hal ini memungkinkan daerah yang 
memiliki jumlah penduduk lebih banyak, memiliki permasalahan yang lebih kompleks dibanding daerah yang jumlah penduduknya lebih sedikit. Sehingga kemungkinan besar anggota DPRD belum menjadikan implementasi e-government sebagai fokus utama yang dibenahi dikarenakan masih adanya permasalahan yang lebih mendesak untuk diatasi sebagai dampak dari jumlah penduduknya yang banyak.

Berdasarkan pengujian parsial, diperoleh hasil bahwa kompetisi politik memiliki arah negatif namun tidak signifikan terhadap implementasi e-government. Artinya setiap terjadi peningkatan kompetisi politik memungkinkan pengurangan implementasi e-government pada suatu pemerintah daerah. Hal ini dapat dilihat dari indeks PeGI tahun 2013 ke tahun 2014, dimana secara umum indeks PeGI menurun sementara jumlah anggota terpilih untuk beberapa pemerintah daerah bertambah. Hal tersebut menunjukkan dengan bertambahnya jumlah anggota terpilih cendrung mengurangi kemungkinan implementasi e-government. Hasil ini sejalan dengan penelitian Garcia-Sanchez (2013) yang menemukan bahwa kompotisi politik memiliki hubungan negatif terhadap pengungkapan informasi non keuangan dimana pengungkapan tersebut merupakan bagian dari implementasi e-government. Hasil penelitian ini juga sejalan dengan penelitian Rahim dan Martani (2015) yang tidak menemukan pengaruh signifikan kompetisi politik terhadap pengungkapan informasi keuangan dan non keuangan pada website pemerintah daerah, dimana pengungkapan informasi melalui website daerah merupakan salah satu implementasi e-government.

Berdasarkan pengujian hipotesis secara parsial yang telah dilakukan, pendapatan asli daerah memiliki nilai probabilitas $0,0306<0,05$, maka sesuai dengan ketentuan $\mathrm{H} 0$ ditolak. Artinya pendapatan asli daerah memiliki pengaruh signifikan terhadap implementasi e-government.

Berdasarkan Tabel 9 terlihat dari 31\% PAD yang diatas rata-rata, hanya $6 \%$ yang memperoleh PeGI kriteria kurang. Sedangkan dari $69 \%$ PAD yang dibawah ratarata, sebesar 44\% memperoleh PeGI kriteria kurang. PAD tertinggi didominasi oleh DKI Jakarta, Jawa Barat dan Jawa Timur dimana ketiga provinsi tersebut juga menduduki peringkat tiga besar pada PeGI tahun 2012-2015. Hal ini menggambarkan bahwa semakin besar PAD maka semakin besar pula PeGI yang menunjukkan implementasi e-government yang semakin baik. Berdasarkan hasil uji parsial diperoleh bahwa PAD memiliki hubungan positif terhadap implementasi e-government. Artinya setiap terjadi peningkatan PAD, maka implementasi e-government juga akan meningkat. Hasil penelitian ini sejalan dengan Sipatuhar dan Sutaryo (2016) yang mengungkapkan bahwa PAD memiliki pengaruh positif signifikan terhadap implementasi e-government. Jika kesejahteraan ekonomi daerah (dilihat dari perolehan PAD) sudah baik, pemerintah akan mempunyai biaya yang cukup untuk melayani masyarakat melalui implementasi e-government. Sebelumnya Dewi dan Haryanto (2013) juga menemukan bahwa pendapatan asli daerah berpengaruh positif signifikan terhadap implementasi e-Government pada pemerintah daerah tingkat provinsi.

Berdasarkan pengujian hipotesis secara parsial yang telah dilakukan opini audit memiliki nilai probabilitas $0,2190>0,05$, maka sesuai dengan ketentuan H0 diterima. Artinya opini audit tidak memiliki pengaruh signifikan terhadap implementasi e-government.

Berdasarkan Tabel 10, dari 63\% data dengan perolehan opini audit wajar tanpa pengecualian (WTP), terdapat $36 \%$ data yang memperoleh PeGI kriteria kurang. Sedangkan dari $37 \%$ data dengan perolehan opini selain WTP, terdapat $26 \%$ data yang memperoleh PeGI kriteria kurang dan $74 \%$ data yang memperoleh opini non wtp telah memperoleh PeGI kriteria baik. DKI Jakarta sepanjang tahun 2012-2015 memperoleh opini selain WTP namun cenderung memiliki nilai PeGI tinggi dan selalu berada pada peringkat tiga besar. Sedangkan NTB yang memperoleh opini WTP selama tahun 20122015 memperoleh rata-rata PeGI dengan kategori kurang. Hal ini mengggambarkan bahwa hasil opini audit tidak mempengaruhi implementasi e-government karena hasil opini WTP tidak memperlihatkan nilai PeGI yang lebih baik. Berdasarkan uji parsial, opini audit memiliki arah negatif terhadap implementasi e-government. Artinya setiap peningkatan opini audit suatu pemerintah daerah, maka terdapat kemungkinan terjadi penurunan implementasi e-government.

Opini WTP menunjukkan bahwa suatu pemerintah daerah telah menyajikan laporan keuangan sesuai dengan prinsip akuntansi berterima umum yang dilengkapi informasi pendukung. Implementasi e-government sendiri membutuhkan informasi yang akurat dan lengkap untuk digunakan oleh pihak yang berkepentingan. Namun berdasarkan hasil uji signifikansi, opini audit tidak berpengaruh terhadap implementasi e-government. Hal ini menunjukkan adanya kemungkinan opini WTP tidak cukup kuat mempengaruhi suatu pemerintah daerah untuk meningkatkan penerapan e-government. Hasil ini sejalan dengan penelitian Utomo dan Aryani (2016) yang menemukan tidak adanya pengaruh signifikan yang dihasilkan dari opini audit sebagai faktor penentu implementasi e-government melalui pengungkapan informasi keuangan pada website pemerintahan.

\section{KESIMPULAN}

Secara simultan kompetisi politik, pendapatan asli daerah dan opini audit berpengaruh signifikan terhadap implementasi e-government pada pemerintah daerah tingkat provinsi yang terdapat pada PeGI tahun 2012-2015. Kemampuan variabel independen dalam menjelaskan perubahan implementasi e-government sebesar $18 \%$ sedangkan sisanya $82 \%$ dijelaskan oleh variabel lain diluar penelitian. 
Secara parsial kompetisi politik dan opini audit tidak memiliki pengaruh signifikan terhadap implementasi e-government pada pemerintah daerah tingkat provinsi tahun 2012-2015. Artinya jika terjadi perubahan kompetisi politik dan opini audit tidak akan menyebabkan perubahan pada implementasi e-government. Pendapatan asli daerah memiliki pengaruh signifikan dengan arah positif, berarti semakin tinggi pendapatan asli daerah suatu provinsi, maka semakin besar tingkat implementasi e-government.

\section{DAFTAR PUSTAKA}

Al-Naimat. 2013. The Critical Factors fo e-government Implementation in Jordan. Proceeding of the 4th International Conference on Computing and Informatics.

Dewi, A. S., \& Haryanto. 2013. Faktor-Faktor yang Mempengaruhi Implementasi e-government (Studi pada Pemerintah Daerah Tingkat Provinsi di Indonesia). Diponogoro journal of Accounting Vol.2 No. 4, 1-15.

Faud, M. R. 2015. Pengantar Akuntansi Keuangan Daerah. Bogor: Ghalia Indonesia.
Garcia-Sanchez. 2013. Deteriminants of Corporate Social Disclosure in Spanish Local Government. Journal of Cleaner Production 39, 60-72.

Rahim, W. M., \& Martani, D. 2015. Analisis Pengaruh Tingkat Akses Internet, Kompetisi Politik, Opini Audit, Karakteristik Pemda dan Karaktersitik Demografi terhadap Pengungkapan Informasi Keuangan dan Non-Keuangan Website Pemerintah Daerah. Perpustakaan UI.

Sipatuhar, R. S., \& Sutaryo. 2016. Faktor-Faktor Penentu Implementasi e-government Pemerintahan Daerah di Indonesia. Simposium Nasional Akuntansi XIX. Lampung.

Utomo, K. C. \& Aryani, Y. A. 2016. The Determinant of Financial Information Disclosure on Indonesian LGs Website. Asia Pasific Fraud Journal Vol.1(1).

Undang-Undang Nomor 32 Tahun 2004 tentang Pemerintahan Daerah. [online]. Tersedia : http:// www.kpu.go.id/dmdocuments/UU_32_2004 Pemerintahan \%20Daerah.pdf [18 November 2016]

Undang-Undang No. 8 Tahun 2012 tentang Pemilihan Umum Anggota DPR, DPD dan DPRD Provinsi dan Kabupaten/Kota.[online]. Tersedia : http:// www.bawaslu. go.id/ sites/default/files/regulasi/ uu_8_2012.pdf [18 November 2016]

Tabel 1. Operasional Variabel

\begin{tabular}{|c|c|c|c|}
\hline Variabel & Definisi Operasional & Indikator & Skala \\
\hline $\begin{array}{l}\text { Ko mpetis i } \\
\text { Politik (X1) }\end{array}$ & $\begin{array}{l}\text { Kompetisi politik digambarkan melalui daya saing untuk menduduki lembaga } \\
\text { legislatif(DPRD), dimana DPRD memiliki posisi dan peran strategis terkait } \\
\text { dengan mengontrol kebijakan keuangan daerah secara ekonomis, efisien } \\
\text { efektif, transparan dan akuntabel (Dewi dan Haryanto, 2013). }\end{array}$ & $\begin{array}{l}\text { Jumlah anggota DPRD } \\
\text { terpilih tingkat provinsi }\end{array}$ & Rasio \\
\hline $\begin{array}{l}\text { Pendapatan Asli } \\
\text { Daerah (X2) }\end{array}$ & $\begin{array}{l}\text { Pendapatan Asli Daerah adalah pendapatan yang diperoleh daerah yang } \\
\text { dipungut berdasarkan peraturan daerah sesuai dengan peraturan perundang- } \\
\text { undangan (Undang-Undang No. } 8 \text { Tahun 2012). }\end{array}$ & $\begin{array}{l}\text { Jumlah realisasi PAD } \\
\text { tahunan tingkat provinsi }\end{array}$ & Rasio \\
\hline $\begin{array}{l}\text { Opini Audit } \\
\text { (X3) }\end{array}$ & $\begin{array}{l}\text { Jumlah temuan yang sedikit akan menghasilkan opini audit yang menunjukkan } \\
\text { pelaporan dan pelaksanaan keuangan yang baik dan benar sehingga pemerintah } \\
\text { daerah cenderung melakukan pengungkapan yang lebih banyak (Rahim dan } \\
\text { Martani, 2015). }\end{array}$ & $\begin{array}{l}\text { variabel dummy dengan } \\
\text { ketentuan: } \\
1=\text { WTP } \\
0=\text { non WTP }\end{array}$ & Nominal \\
\hline $\begin{array}{l}\text { Implemen-tasi } \\
\text { e-Government } \\
\text { (Y) }\end{array}$ & $\begin{array}{l}\text { Menurut Direktorat e-Government, implementasi e-Government dapat dinilai } \\
\text { melalui lima kriteria yang harus dipenuhi yaitu kebijakan, kelembagaan, } \\
\text { infrastruktur,aplikasi dan perencanaan. }\end{array}$ & $\begin{array}{l}\text { Indeks Pemering-katan } \\
\text { e-Government }\end{array}$ & Rasio \\
\hline
\end{tabular}

Tabel 2. Kriteria Pengambilan Sampel

\begin{tabular}{ccc}
\hline No & \multicolumn{1}{c}{ Kriteria } & Jumlah \\
\hline 1 & $\begin{array}{l}\text { Provinsi di Indonesia yang terdapat pada } \\
\text { Pemeringkatan e-Government Indonesia (PeGI) }\end{array}$ & 34 \\
2 & $\begin{array}{l}\text { Provinsi di Indonesia yang tidak terdapat pada } \\
\text { Pemeringkatan e-Government Indonesia (PeGI) }\end{array}$ & \\
& & \\
& tahun 2012-2015 \\
\hline & Jumlah pemerintah daerah tingkat provinsi yang & 13 \\
& terdapat pada Pemeringkatan e-Government & \\
& Indonesia (PeGI) tahun 2012-2015. & \\
Sumber: Badan Pusat Statistik dan Pemeringkatan E-Government \\
Indonesia.
\end{tabular}

Tabel 3. Hasil Pengujian Statistik Deskriptif

\begin{tabular}{lcccc}
\hline & $\begin{array}{c}\text { Kompetisi } \\
\text { Politik }\end{array}$ & $\begin{array}{c}\text { PAD (dalam } \\
\text { miliaran rupiah) }\end{array}$ & $\begin{array}{c}\text { Opini } \\
\text { Audit }\end{array}$ & $\begin{array}{c}\text { Implementasi } \\
\text { E-Government }\end{array}$ \\
\hline Mean & 75,384 & $5.936,332$ & 0,634 & 2,565 \\
Std. Dev. & 22,743 & $8.157,550$ & 0,486 & 0,490 \\
Minimum & 45 & 140,397 & 0 & 1,61 \\
Maximum & 106 & $33.686,177$ & 1 & 3,39 \\
\hline Sumer
\end{tabular}


Tabel 4. Hasil Uji Signifikansi Fixed Effect (Uji Chow)

Redundant Fixed Effects Tests

Equation: Untitled

Test cross-section fixed effects

\begin{tabular}{lccc}
\hline Effects Test & Statistic & d.f. & Prob. \\
\hline Cross-section F & 5.311185 & $(12,36)$ & 0.0000 \\
Cross-section Chi-square & 52.987472 & 12 & 0.0000 \\
\hline
\end{tabular}

Sumber : Output Eviews 8 (data diolah)

Tabel 5. Hasil Uji Hausman

Correlated Random Effects - Hausman Test

Test cross-section random effects

\begin{tabular}{lccc}
\hline Test Summary & Chi-Sq. Statistic & Chi-Sq. d.f. & Prob. \\
\hline Cross-section random & 2.094469 & 3 & 0.5530
\end{tabular}

Sumber : Output Eviews 8 (data diolah)

Tabel 6. R-squared Metode Random

\begin{tabular}{llll}
\hline \multicolumn{4}{c}{ Weighted Statistics } \\
\hline R-squared & 0.182948 & Mean dependent var & 1.014257 \\
Adjusted R-squared & 0.131882 & S.D. dependent var & 0.288800 \\
S.E. of regression & 0.269083 & Sum squared resid & 3.475471 \\
F-statistic & 3.582592 & Durbin-Watson stat & 1.965337 \\
Prob(F-statistic) & 0.020373 & & \\
\hline
\end{tabular}

Sumber: Output Eviews 8 (data diolah)

Tabel 7. Hasil Uji Parsial

\begin{tabular}{crrrr}
\hline Variable & Coefficient & Std. Error & t-Statistic & Prob. \\
\hline KP & -0.009502 & 0.009206 & -1.032064 & 0.3072 \\
PAD & 0.308065 & 0.138258 & 2.228185 & 0.0306 \\
OA & -0.131453 & 0.105551 & -1.245397 & 0.2190 \\
C & -3.267987 & 2.372166 & -1.377638 & 0.1747 \\
\hline
\end{tabular}

Sumber: Output Eviews 8 (data diolah)

Tabel 8. Data Kompetisi Politik diatas dan dibawah Rata-Rata

\begin{tabular}{lccc}
\hline \multirow{2}{*}{ Keterangan } & PeGI Baik & PeGI Kurang & \multirow{2}{*}{ Total } \\
\cline { 2 - 3 } & Jumlah & Jumlah & \\
\hline KP diatas rata-rata & 20 & 4 & 24 \\
KP dibawah rata-rata & 15 & 13 & 28 \\
Jumlah & 35 & 17 & 52 \\
\hline
\end{tabular}

Sumber : Data diolah

Tabel 9. Data Pendapatan Asli Daerah diatas dan dibawah Rata-Rata

\begin{tabular}{lccc}
\hline \multirow{2}{*}{ Keterangan } & PeGI Baik & PeGI Kurang & \multirow{2}{*}{ Total } \\
\cline { 2 - 3 } & Jumlah & Jumlah & \\
\hline PAD diatas rata-rata & 15 & 1 & 16 \\
PAD dibawah rata-rata & 20 & 16 & 36 \\
Jumlah & 35 & 17 & 52 \\
\hline
\end{tabular}

Sumber : Data diolah
Tabel 10. Data Opini Audit WTP dan non WTP

\begin{tabular}{lccc}
\hline \multirow{2}{*}{ Keterangan } & PeGI Baik & PeGI Kurang & \multirow{2}{*}{ Total } \\
\cline { 2 - 3 } & Jumlah & Jumlah & \\
\hline Opini Audit WTP & 21 & 12 & 33 \\
Opini Audit non WTP & 14 & 5 & 19 \\
Jumlah & 35 & 17 & 52 \\
\hline
\end{tabular}

Sumber : Data diolah

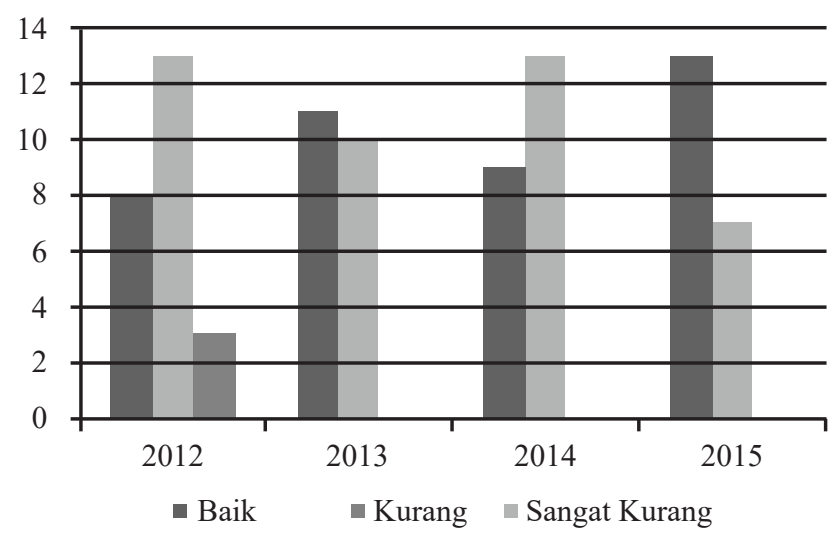

Sumber: Pemeringkatan e-government Indonesia KEMKOMINFO (data diolah)

Gambar 1. Pemeringkatan E-Government Tingkat Provinsi Tahun 2012-2015

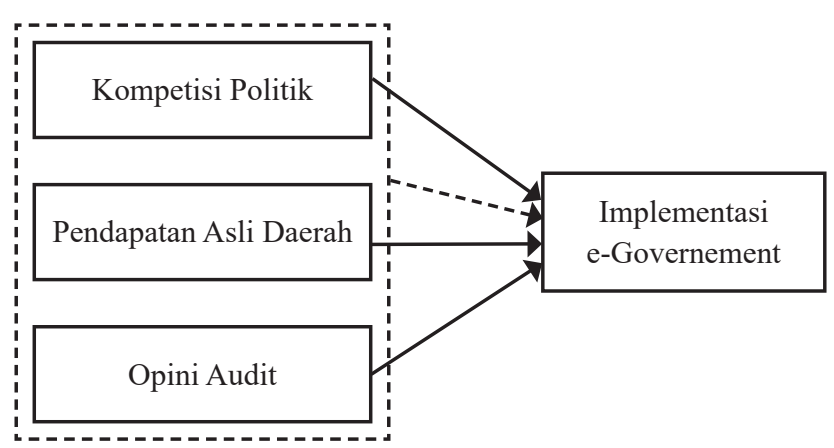

: Berpengaruh Secara Parsial

Berpengaruh Secara Simultan

Gambar 2. Kerangka Pemikiran 